\title{
反射音の空間バランスに着目した音に包まれた感じの定量化方法 A NEW OBJECTIVE MEASURE FOR EVALUATION OF LISTENER ENVELOPMENT FOCUSING ON THE SPATIAL BALANCE OF REFLECTIONS
}

\author{
羽入敏 樹*, 木村 翔**, 千葉 俊*** \\ Toshiki HANYU, Sho KIMURA and Suguru CHIBA
}

\begin{abstract}
We conducted seven subjective experiments in order to clarify the effects of the direction of arrival, spatial distribution, temporal distribution and listening level of reflections on listener envelopment $(\mathrm{LEV})$. As a results, it became clear that the contribution of a reflection on LEV depends on the direction of arrival of other reflections and that it is not possible to make independent evaluations. LEV cannot be adequately evaluated with a physical index that weights and integrates individual reflection by the direction of arrival like the lateral energy ratio. It is necessary to consider the mutual effects of reflections by some means and to quantify the spatial distribution of reflections. Accordingly, we proposed SBTs quantifying the spatial distribution of reflections using point of gravity time Ts for each direction and demonstrated that it is possible to obtain a good correlation with the psychological scores of LEV.
\end{abstract}

Keywords : Listener envelopment, Spatial impression, Sound field, Spatial balance, Spatial information, Point of gravity time 音に包まれた感じ、空間印象、音場、空間バランス、空間情報、時間重心

\section{1.はじめに}

コンサートホール等の室内音響設計を、より適確に進めていく上 では、室の大きさや形状、壁面材料などの建築的諸条件によって創 出される室内音場の物理特性と受聴者が感じる心理量との関係をさ らに明確にしていく必要がある。コンサートホールの音場を評価す る重要な属性の一つとして音場の空間印象がある。Barron[1] らが 側方反射音と音場の空間印象に関する研究成果を発表して以来、空 間印象を評価する指標として側方エネルギ率が定着しつつある。空 間印象は、少なくとも見かけの音源の幅 (Auditory Source Width： ASW）と音に包まれた感じ (Listener Envelopment : LEV) の二つの 要素感覚に分けられることが森本らによって明らかにされている [2]。そのうちASW に関しては研究例が多く、物理指標も種々提案 されているが、LEVに関してはまだ研究例が少ない。

最近ではLEV の物理指標として Bradley らが $80 \mathrm{~ms}$ 以降の残響部 の側方反射音レベル[3,4]、Beranek が両耳間相関度[5]を提案してい る。一方、側方以外の方向から到来寸る反射音に着目した研究例も 見られる。例えば、森本らは両耳間相関度や側方エネルギ率が一定 でも反射音の前後エネルギ比が変化すると LEV が変化する[6]こと を報告し、古屋らは両耳間相関度を大きくする要因となる上方反射 音が LEV に貢献すること[7]を報告している。また、筆者らは側方
エネルギ率が大きくなる条件よりも、反射音があらゆる方向から受 聴者を取り囲むような条件ほど音に包まれた感じが増す現象につい て報告した $[8]$ 。このような研究事例から見られるように、LEVに 関しては、側方エネルギ率や両耳間相関度以外の要因が存在してい ることが推察される。筆者らは様々なホールの空間情報を測定して データを蓄積してきたが、実際のホールにおいても比較的響きが良 いとされるシューボックスタイプのホールでは、側方だけでなくあ らゆる方向（特に上方や後方）から多くの反射音が受聴者を取り囲 むように到来している。

そこで本報では、これらの現象を系統的に検討するため、反射音 の到来方向、空間分布、残響時間、受聴レベルが音に包まれた感じ (LEV)に及ぼす影響を7つの心理実験を行って調べることにした。 また、それらの実験結果から LEV の物理指標が備えるべき必要条 件について考察し、ある反射音の LEV への寄与が、他の反射音の 到来方向に依存し、独立に評価できないことを明らかにした。さら にその結果に基づいて、反射音の空間分布を定量化する方法につい て検討を行なった。

\section{2. 実験方法}

実験は全て無響室において、シミュレーション音場を用いて行
* 日本大学短期大学部建設学科 助手・工博

** 日本大学理工学部建築学科 教授・工博

*** 高砂熱学工業獭）工修
Research Assoc., Dept. of Construction, Nihon University Junior College, Dr. Eng. Prof., Dept. of Architecture, College of Science and Technology, Nihon Univ. Dr. Eng.

Takasago Thermal Engineering Co., Ltd., M. Eng. 
なった。音場再生には、無響室に設置された図 1 に示す $16 \mathrm{ch} の マ$ ルチチャンネル音場再生システムを用いた。スピーカは、両耳を含 む水平面内で被験者から $1.5 \mathrm{~m}$ の距離に $22.5^{\circ}$ の等間隔に設置した。 実験にあたっては、16 台のスピーカの中から必要な台数のスピー 力を選択して直接音あるいは残響音を再生した。再生に必要な方向 別応答は、図 2 に示寸基本音場を加工した仮想音源分布から合成し た。これらの方向別応答波形にモーツァルト作曲「ディベルティメ ント第三楽章」の約 10 秒間を畳み込んだものを刺激として用いた。 なお、本実験においては初期反射音と後期残響部を区別していない。 本文中で残響音と記しているときは、特に後部残響音等の記述が無 い限り直接音以外のすべての反射音を指している。

本論文の研究目的は、“音に包まれた感じ”に影響を及ぼす要因 を抽出し、抽出した要因を考虑して“音に包まれた感じ”を定量 化するための評価モデルの仮説を構築することにある。したがって、 まず考えられる要因に関してそれぞれ独立した実験を計画し、実験 ごとにそれぞれの要因の“音に包まれた感じ”への影響を精度良 く調べることにした。そのため心理実験手法として、各実験間のデ 一タ比較はできなくなるが、刺激に対する判断の信頼性、判断の容 易さ、被験者数の制的などを考慮し、シェッフェの一対比較法を用 いることにした。

被験者は、建築音響の研究を行っている学生 5〜10名で、被 験者数および被験者のグループ構成は実験ごとに異なっている。刺 激対は、被験者ごとにランダムに異なる順番で提示した。順序効果 を相殺するために、刺激の順番を入れ替えた刺激対についても評価 してもらった。その際、実験時間が長くなりすぎないように配慮し て2回の実験に分けた。結果として、各被験者は同じ組み合わせの 刺激対を刺激の順序を変えて 2 回評価したことになる。被験者には、 各刺激対に対して、後の音場が前の音場と比較してどれだけ音に包 まれているかを、前の音場と比べて“1．非常に包まれている感 じ”、“2．かなり包まれている感じ”、“3. 少し包まれている感 じ”、“4．同じ”、“5．少し包まれていない感じ”、“6．かなり 包まれていない感じ”、“7. 非常に包まれていない感じ”の7 段 階で判断してもらった。被験者は7段階評価に対応する番号を口頭 で答え、実験者は別室においてそれをマイクロホンでモニターして 記録した。なお、被験者には“音に包まれた感じ”を“まわりか ら到来する音に包まれている感じあるいは浸っている感じ”であ ると教示した。結果の処理は、刺激対の順序効果を考慮したため浦 の変法[9]に従って行った。



図1 マルチチャンネル音場再生システムのブロックダイヤグラム

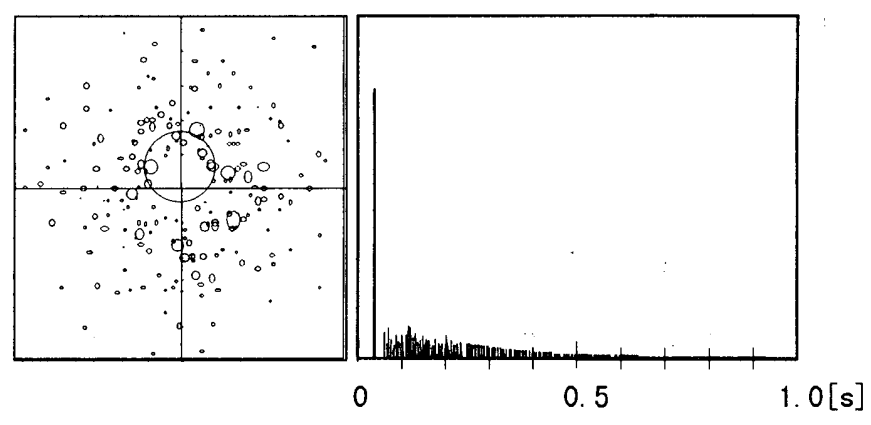

図2 基本音場の仮想音源分布と仮想音源を時系列に再合成した 無指向性インパルス応答 (残響時間 2.0 秒)

\section{3. 反射音到来方向の影響}

Barron らは初期反射音の呈示角度を変化させて、反射音到来方向 の Spatial Impression(SI)への影響を調べLfを提案した[1]。Barron は 論文中[10]で、SI を "the source appeared to broaden”と表現している ことから、おそらくSIはASWに近いものであったと思われる。LEV に関しては、先に述べたように Bradley が反射音の到来角度分布と LEV との関係を心理実験により調べ、側方反射音が存在するとき に、顕著な音に包まれた感じが得られることを明らかにしている $[3,4]$ 。しかし、反射音の到来角度分布を調心゙たもので、同じ時間構 造の反射音の到来方向をパラメータにして LEV への影響を調べた ものではない。さらに、反射音の到来方向は正面に対して $\pm 90^{\circ}$ の側方までであり、後方から到来する反射音の影響は未知である。 森本らは後方反射音に着目し、前後エネルギ比を変化させて LEV に及ぼす影響を調べている[6]。しかし、この実験も前方と後方と いう大きなエリア分けであり、反射音の到来方向をパラメータとし た実験ではない。

そこでまず、反射音の到来方向が LEV に及ぼす影響を調べるた めの実験を行なった。

\section{3-1. 実験条件}

実験依 3 に示寸ように、正面と左右の 3 方向から直接音あるい は残響音を呈示するシンプルな音場を用いて行った。な挔、表 1 に 示すように、正面スピーカから直接音のみ呈示（実験 1 ）、正面ス ピーカに残響音を付加（実験 2）の2つの条件について実験を行っ た。各スピーカに対応した方向別応答波形を図 4 に示す。方向別応 答の残響音は、図 2 に示した仮想音源分布を実験 1 では空間的に左 右 2 等分、実験 2 では 3 等分し、各エリアに存在する仮想音源を時 系列に合成することによって作成した。また、各スピーカに対忍し た方向別応答は変化させず、同じ時間構造を持つ反射音の到来方向 が変化したときの LEV 八の影響を調べることにした。両実験で用 いた全音場の無指向性インパルス応答は不変で、残響時間は約 2.0 秒である。その他の実験条件は以下のとおりである。

A. 左右の残響音の呈示方向: $\pm 22.5^{\circ} \sim \pm 157.5^{\circ}$ まで $22.5^{\circ}$ きざ 如の 7 方向

B. 刺激対の総数 : 21 対

C. 刺激の呈示レベル : 受聴点で約 $72 \mathrm{~dB}(\mathrm{~A})$

D. 被験者：5名（各人 2 回ずつ評価） 


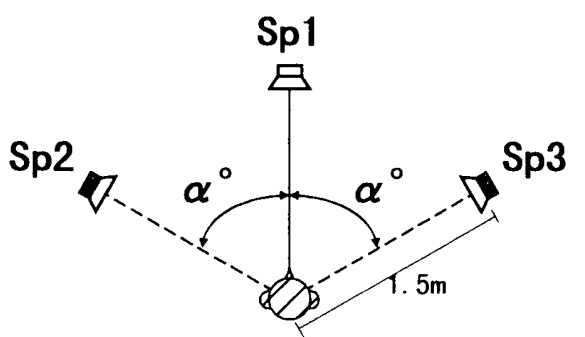

図3 実験 $1 、 21$

表1 実験1、21における音場条件

\begin{tabular}{ccc}
\hline & 実験1 & 実験2 \\
\hline$S p 1$ & 直接音のみ & 直接音十残響音 \\
$\mathrm{Sp2}$ & 残響音 & 残響音 \\
$\mathrm{Sp3}$ & 残響音 & 残響音 \\
\hline
\end{tabular}

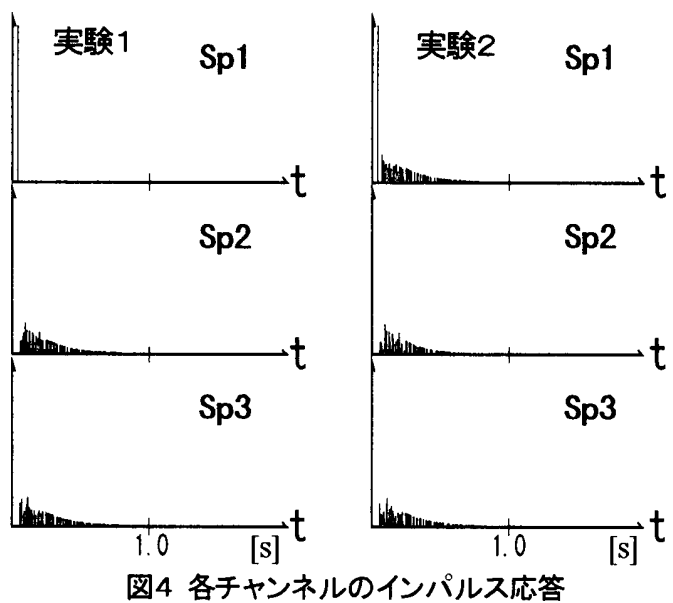

\section{3-2. 結果と考察}

実験 1 および2の結果を図 5、図 6 に、側方反射音レベル LG[3] の変化を図 7 に示す。3-1 式で表わされる LG は、左右の残響音呈 示方向 $90^{\circ}$ をピークとして前後対称なカーブとなる。

$$
L G_{80}^{\infty}=10 \log \left[\int_{80}^{\infty} p^{2}(t) \cos ^{2}(\alpha) d t / \int_{0}^{\infty} p_{A}^{2}(t) d t\right]
$$

ただし、 $P_{A}(t)$ は無響室の $10 \mathrm{~m}$ 点での測定システムの応答

正面スピーカから直接音のみ呈示した実験 1 では、LEV は LG の変化とよく対応しており $90^{\circ}$ で最も大きくほぼ前後対称なカー ブとなっている。正面スピーカに残響音を付加した実験 2 において も、90で LEV が最も大きくなっている。したがって、側方から 到来寸る残響音ほど LEV への寄与が大きいことがわかる。

LG はその定義から正面方向から到来する残響音に何ら影響を受 けないはずである。しかし、正面方向から残響音が到来する実験 2 では、左右の残響音を前方より後方から呈示した方が LEV の評価 が高くなっている。これは、正面方向の残響音が LEV に何らかの 影響を及ぼしていることを示しており、LG のような側方エネルギ 率では説明できない。一方、この現象が前後エネルギ比の影響であ れば、実験 2 だけではなく実験 1 の結果にも現れるはずである。す
なわち、正面方向の残響音の有無によって LEV の変化の傾向が異 なる現象は、左右の残響音が正面方向の残響音と相互に作用し合い LEVに影響を及ぼした結果と考えることができる。側方エネルギ 率でも前後エネルギ比でも説明できないこのような効果の存在は、 残響音の到来方向だけでは LEV を十分に評価できないことを示唆 している。

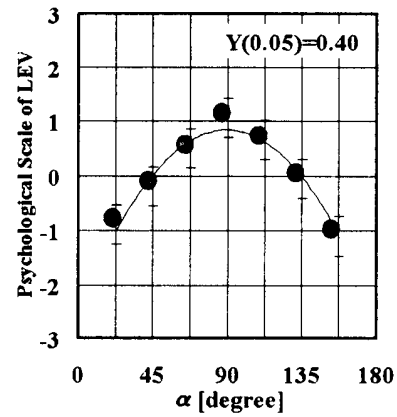

図5 実験1の心理尺度值

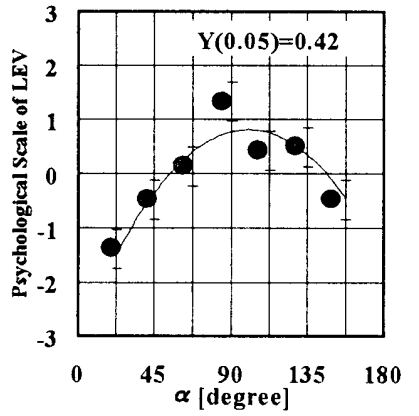

図6 実験2の心理尺度值

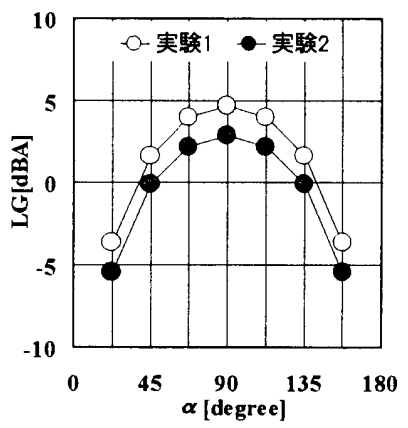

図7 実験 $1 、 2$ における LG の変化

\section{4. 反射音の空間分布の影響}

反射音の空間分布と LEV の関係については、Bradley が心理実験 を行って調べている[3,4]。Bradley の実験では、側方エネルギ率が そうであるように、反射音到来方向による LEV への寄与は両耳軸 に対して前後対称であるという仮定を導入している。その仮定によ り、残響音の呈示方向を正面スピーカのみ、左右 $\pm 35^{\circ}$ を加えた 3 台のスピーカ、さらに $90^{\circ}$ を加えた 5 台のスピーカの 3 条件 の空間分布を使っており、後方から残響音を呈示していない。反射 音の奇与が両耳軸に対して前後対称であるという仮定が LEV にお いて成り立つかどうかは疑問である。前後エネルギ比の影響を調べ た森本らの論文[6]は、その仮定が成り立たないことを示唆してい る。また、今回筆者らが行なった実験 2 の結果は、少なくとも正面 方向に残響音が存在する場合にはその仮定が成り立たないことを示 している。

そこで、反射音の空間分布が LEVに及ぼす影響を調べると共に、

実験 2で見られた反射音の相互作用を検証することを目的として次 の心理実験を行なった。

\section{4-1. 実験条件}

実験は図 8、図9に示すように、実験 2 の条件に、到来方向を 固定した残響音を前方 $\pm 45^{\circ}$ に加えた音場（実験 3 ）、後方 $\pm 135^{\circ}$ に加えた音場（実験 4 ）を用いて行った。

各スピーカに対応した方向別応答波形を図 10 に示寸。方向別 
応答の残響音は、図 2 に示した仮想音源分布を空間的に 5 等分し、 各エリアに存在する仮想音源を時系列に合成することによって作成 した。また実験 1、2 と同様に、各スピーカに対応した方向別応答 は変化させず、同じ時間構造を持つ反射音の到来方向が変化したと きの LEV への影響を調べることにした。両実験で用いた全音場の 無指向性インパルス応答は不変で、残響時間は約 2.0 秒である。そ の他の実験条件は以下のとおりである。
A. 左右の残響音の呈示方向 : $\pm 22.5^{\circ} \sim \pm 157.5^{\circ}$ まで $22.5^{\circ}$ き ざみで固定 $S p$ 方向を除いた 6 方向
B. 刺激対の総数 : 15 対
C. 刺激の呈示レベル : 受聴点で約 $72 \mathrm{~dB}(\mathrm{~A})$
D. 被験者：10名（各人 2 回ずつ評価）

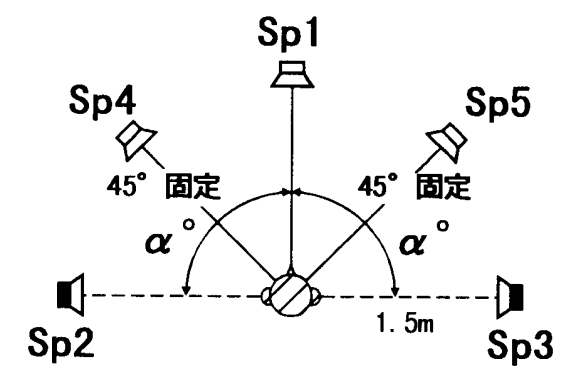

図8 実験引におけるスピーカ町贯图



図9 実験4におけけるスピーカ配量図

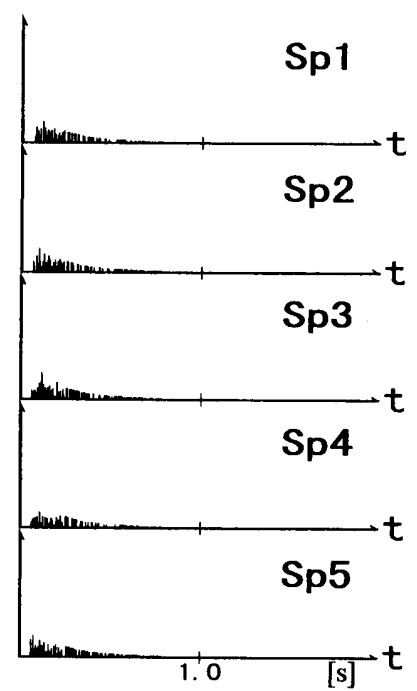

図10 各チャンネルにおけるインパルス応答

\section{4-2. 結果と考察}

実験 3、4の結果を図 1 1、図 12 に、各条件における LG と前
後エネルギ比をそれぞれ図 13 、図 14 亿示す。LG は呈示方向を 変化させた左右の残響音 (以下、単に左右残響音) の到来方向が $90^{\circ}$ の条件をピークとして実験 $1 、 2$ と同様に前後対称なカーブを描き、 実験 3 と 4 で全く同じ值となる。前後エネルギ比は、実験 3、4 もに左右残響音が前方より後方にある場合に大きな值となる。すな わち、左右残響音の到来方向をパラメータとした側方エネルギ率お よび前後エネルギ比の変化は、固定 S p からの残響音（以下、単に 固定残響音）の到来方向に依存せず同じ傾向を示す。

固定残響音を前方 $\pm 45^{\circ}$ に加えた実験 3 の結果（図 11）を見る と、左右残響音が前方より後方にある方が LEV は大きくなり LG の変化と符合しない。左右残響音が前方より後方にある場合に LEV が大きくなることは前後エネルギ比と対応する。

固定残響音を後方 $\pm 135^{\circ}$ に加えた実験 4 （図 12）では、実験 3 と異なり左右残響音が後方より前方にある方が LEV は大きい值と なった。これはLGおよび前後エネルギ比の変化と符合しない。

実験 3 と 4 の結果を比べてみると、左右残響音の到来方向をパラ メータとした LEV の変化は、固定残響音の到来方向に依存するこ とがわかる。このような変化は、ある反射音の LEV への寄与が、 他の反射音の到来方向に依存し、独立に評価できないことを示して いる。したがって、側方エネルギ率のように個々の反射音を到来方 向で重み付けして積分する物理指標では LEV を十分に評価できな い可能性がある。LEV を評価するには、反射音相互の作用を何ら かの方法で考慮する必要があるものと考えられる。

図 15 は実験 $3 、 4$ の各条件におけるスピーカ配置を LEV の大 きい順に並べたものである。これを見ると、スピーカが受聴者を空 間的にバランス良く取り囲んでいる条件ほど LEV が大きいことが わかる。これは以前筆者らの行った実験[8]で得られた “反射音が あらゆる方向から受聴者を取り囲むような条件ほど音に包まれた感 じが大きい”という知見と一致する。また、実験 3 と 4 における 左右残響音が $22.5^{\circ}$ と $157.5^{\circ}$ の音場は、左右残響音の到来方向が 両耳軸に対して互いに前後対称の関係にあり、LG も全く同じ值で ある。しかし、両者の LEVには有意な差がみられる。このことは、 反射音の LEV への寄与は、他方向に反射音が存在する場合には必 ずしも両耳軸に対して前後対称とはならないことを示している。

以上の結果をまとめると、個々の反射音を到来方向で重み付けし て積分する方法では LEV を十分に評価できない可能性があり、反 射音相互の作用を考虑して反射音の空間分布を定量化する必要があ ると考えられる。

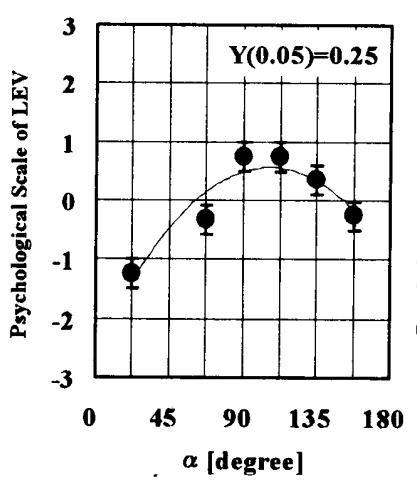

図11 実験3の心理尺度值

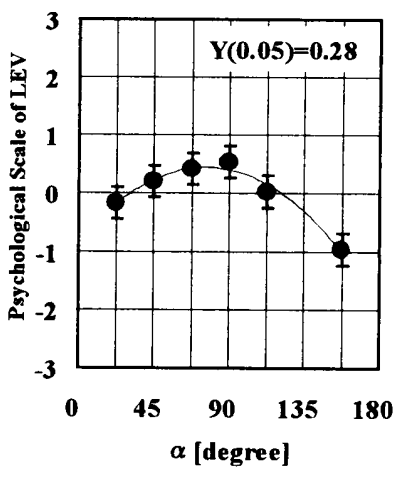

图12 実跧 4 の心理尺度值 




図13 実験3および実験4 における LG

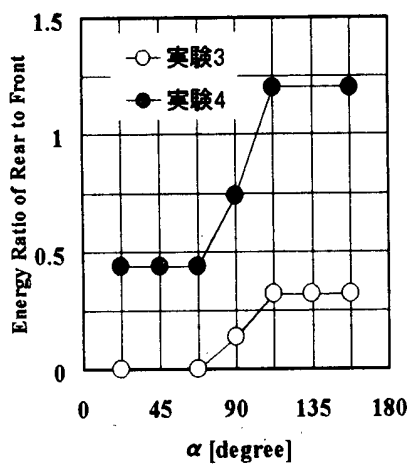

図14 実験3および実験4 における前後エネルギ比

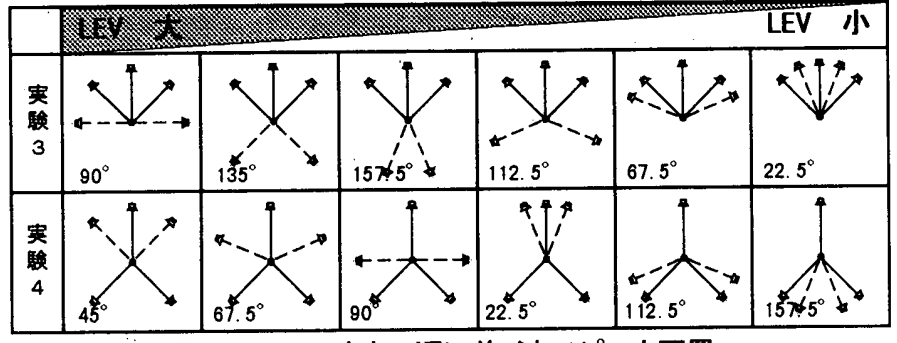

図15 LEV の大きい順に並ベたスピ一力配置

\section{5. 残響時間と受聴レベルの影響}

Bradley は、反射音の時間分布と LEV の関係について心理実験を 行ない、直接音に対する反射音のレベルとディレイが大きいほど、 または残響時間が長いほどLEVが増すことを明らかにしている[3]。 さらに、受聴レベルが LEV に及ぼす影響も非常に大きいことを明 らかにしている[4]。Bradley はこれらの実験を根执にして $80 \mathrm{~ms}$ 以 降の残響部の側方反射音レベル LG を提案している。LG は $80 \mathrm{~ms}$ までの反射音の影響を全く考慮していない。実音場では一般に、 $80 \mathrm{~ms}$ 以内にレベルの大きい初期反射音が存在しており、レベルが 大きいためにディレイが小さくても LEV への影響が大きい可能性 がある。さらに、直接音や $80 \mathrm{~ms}$ までのレベルの大きい初期反射音 にそれ以降の反射音の効果がマスクされる可能性も否定できない。

また、LG は定義式の分母がストレングス G と同様に、無響室の $10 \mathrm{~m}$ 点における測定システムの応答になっている。すなわち LGは、 側方に重み付けした絶対レベルとなっており、直接音に対する相対 的な時間構造や空間構造は考虑していない。

ここでは、反射音の時間構造と受聴レベルが LEV に及ぼす影響 に関する基礎的な知見を得るために、残響時間と受聴レベルを要因 とした心理実験を行った。

\section{5-1. 実験条件}

実験は、反射音の空間分布は変化させずに残響時間だけを変化さ せた場合 (実験 5 )、残響時間と空間分布の両方を変化させた場合 (実験 6 )、反射音の時間構造、空間分布が全く同じ条件で受聴レ ベルを変化させた場合（実験 7) について行った。

実験 5 は、図 1 に示したスピーカ全てを使用して 16 万向から残 響音を呈示する条件で、反射音の到来時間を変えずにエネルギ減衰 だけを変化させる事で、残響時間 1.0 秒 3.0 秒まで 0.5 秒刻みの 5 音場を設定した。
実験 6 は、図 16 に示すように、反射音の空間分布に関して音源 方向から左右 \pm 45 度に分布する 5 台のスピーカを用いた条件と、 左右 \pm 90 度に分布する 9 台のスピーカを用いた条件の 2 条件を、 残響時間に関しては 1.0 秒、 2.0 秒、 3.0 秒の 3 条件とし、合計 6 音 場を設定した。

実験 7 は、実験 5 と同様に 16 方向から残響音を呈示する条件で、 反射音の空間分布、到来時間、エネルギ減衰を変化させずに受聴レ ベルだけを-6〜+6dB まで3dB刻みで変化させた 5 音場を設定した。 各実験に用いた音場の無指向性インパルス応答を図 17 に示す。 その他の赛験条件は以下のとおりである。

A. 刺激の呈示レベル : 実験 5 、実験 6 は受聴点において 72dB(A)、

実験 7 はレベル $\pm 0 \mathrm{~dB}$ の音場で受聴点レベル $72 \mathrm{~dB}(\mathrm{~A})$

B. 被験者 : 10 名（各人 2 回ずつ評価）

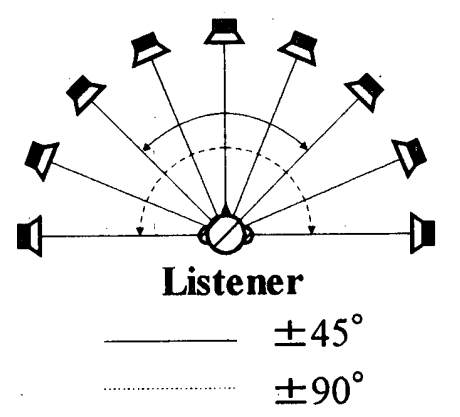

図16 実験6のスピーカ配置



図17 実験に用いた音場の無指向性インパルス答

\section{5-2. 結果と考察}

\section{残隌時间の影隌}

残響時間を変化させた実験 5 の結果を図 18 に示す。これを見る と残響時間が長くなるにしたがって LEV も大きくなる傾向にある。 
また、 2.5 秒と $3: 0$ 秒の間を除く全ての条件間で有意な差が認めら れることから、音の到来方向が同じでも残響時間が違うと空間印象 が異なることがわかる。

残響時間と反射音の空間分布の両方を変化させた実験 6 の結果を 図 19 に示す。空間分布が同一の条件内で比較すると、実験 5 と同: 様に残響時間が長くなる程 LEV の評価が高くなっている。空間分 布の違いを見ると、左右土45 度の条件よりも、より広範囲に反射 音到来方向が分布している \pm 90 ，度の方が全体的に評価が高くなっ ている。しかし、士90、度の条件でも、残響時間が 1.0 秒と短い場 合は土45 度の 2.0 秒以上の条件より LEV の評価が下回る結果とな っている。

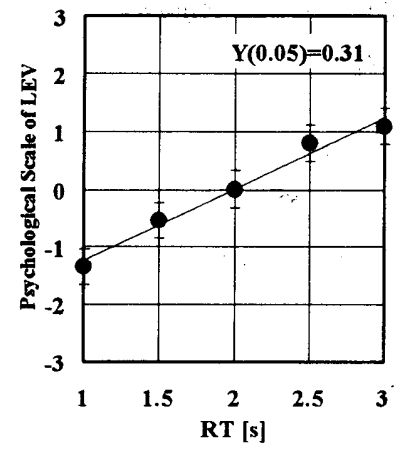

図18 実跨5の心理尺度値

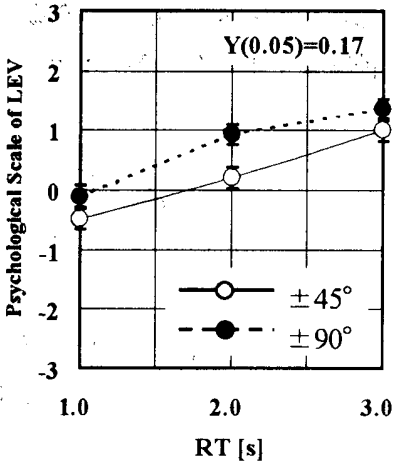

図19 実験6の心理尺度值

実験 5 の各条件における側方エネルギ率 Lf[1]、後期側方反射音 レベル LG、Thiele，の指向拡散度 $\mathrm{d}[11]$ の変化をそれぞれ図 20 、図 21 、図 22 に示す。なお、図 22 には積分区間を $80 \mathrm{~ms} 、 300 \mathrm{~ms}$ に限定した d もあわせて示した。これをみると、初期の $80 \mathrm{~ms}$ まで の反射音に着目した指標 Lf や $\mathrm{d}(80)$ の、RT による変化は小さい。 一方 LEV の評価（図18）には、はっきり差が表れている。この ことから、空間印象は初期反射音だけでなく、少なくとも $300 \mathrm{~ms}$ 程度までの後部残響音を含めた反射音に影響を受けていると思われ る。また、LG、d などの指標は残響時間の変化と独立ではなく、 残響時間が長くなるとこれらの值は共に大きくなる。すなわち、反 射音の時間構造 $(\mathrm{RT})$ と空間情報(LGd)は独立に扱えない。このこと は、反射音の時間構造と空間情報の影響をそれぞれ定量化し、後で 結合することによって LEV を評価することは困難であることを示 している。LEV を評価する際には両者を統合的に扱って同時に定 量化する必要があると考えられる。

\section{受聴レベルの影響}

受聴レベルを変化させた実験 7 の結果を図 23 に示す。これを見 ると、受聴レベルが大きいほど LEV が大きくなり、実験 5 と同様 に有意な差が認められる。実験 7 では、受聴レベルだけを変化させ ており、音場を特徵づける時間応答や空間情報ば全て不変である。 したがって、Bradley の実験結果[4]と同様に時間応答や空間情報に 加えて受聴レベルも LEVに影響を与えることが確認された。また、 受聴レベルと反射音の直接音に対する相対的な時間構造や空間構造 とは物理的には完全に独立したパラメータとして扱うことができる。 このため、両者を独立に定量化し、後でその影響を結合することに よって LEV を評価できる可能性がある。

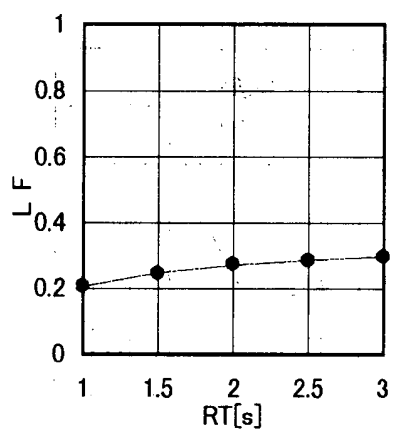

図20実験5における Lf

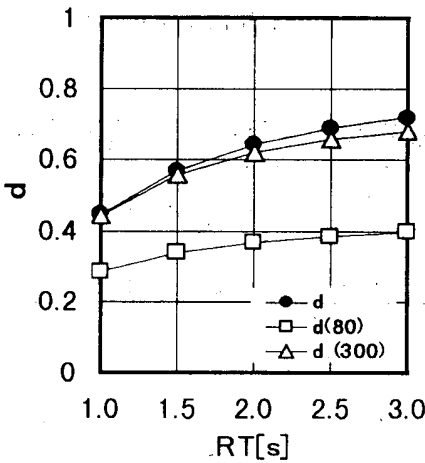

図22 実験5におけるd值

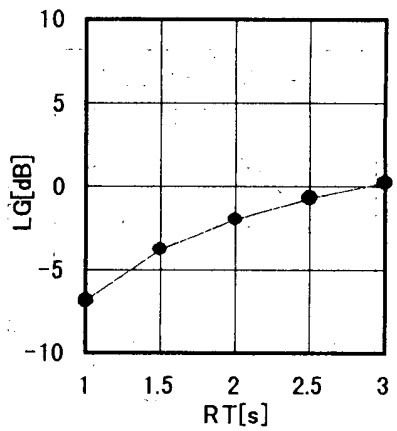

図21 実験5における LG

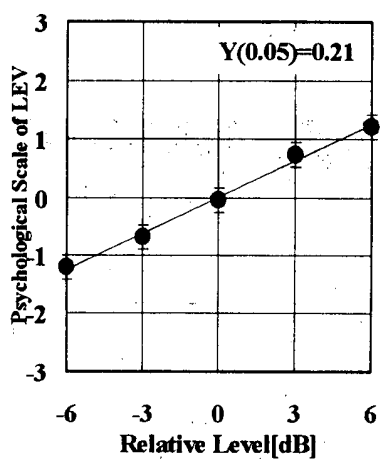

図23 実験7の心理尺度値

\section{6. 音に包まれた感じの定量化方法の検討}

これまでの実験結果から LEV の物理指標が備える心゙き必要条件 について考察し、定量化方法について検討した。 6-1. LEV の物理指標の必要条件

今回の実験と以前筆者らが行った基礎実験 $[8]$ （実験 $\mathrm{A}$ ）、および Bradley が行った一連の実験の結果から導き出される知見を以下に まとめた。

\section{反射音の到来方向の影響}

a. 側方から到来する反射音ほど LEV への寄与が大きい（実験 1)。

b. 正面から到来する反射音の LEVへの影響はゼロではない（実 験 2)。

\section{反射音の空間分布の影響}

c. 個々の反射音の LEV への寄与は他の反射音の到来方向に依存 する(実験 2、3、4)。

d. 反射音到来方向の空間分布が広範囲の場合に LEV が大きくな 马 (実験 A、6、Bradley)。

e. 反射音到来方向の空間的バランスが良い場合に LEV が大きく なる（実験 2、3、4）。

反射音の時間分布の影響

f.，直接音に対する反射音エネルギ比が大きくなると LEV が増す (実験 A、Bradley)。

g. 直接音に対する反射音の遅れ時間が大きくなると LEV が増す (Bradley)。

h. 残響時間が長くなると LEV は大きくなる（実験 5、6、Bradley）。 受聴レベルの影響

i. 受聴レベルが大きくなると LEV も大きくなる (実験 7、Bradley)。 これらの現象を説明できることが LEV の物理指標の必要条件と 
考え、LEV 定量化方法について検討した。なお、鉛直方向の反射 音の影響も考虑する必要があると思われるが、今回は水平面内に限 定して検討寸る。また、受聴レベルは一定の条件とし、まずは反射 音の直接音に対する相対的な時間、レベル、空間構造の定量化を検 討することにした。

\section{6-2. LEV の定量化方法}

反射音の時間分布に関する知見 $\mathrm{f} 、 \mathrm{~g} 、 \mathrm{~h}$ の効果を同時に説明でき る物理指標として EDT、Ts があげられる。EDT は反射音の時間的 変化やエネルギ的な変化に対して必ずしも連続に変化しない。また、 数本の反射音によるシンプルな音場など EDT が計算できない場合 がある。一方、Ts は反射音の時間的変化や直接音対反射音エネル ギ比の変化に対応して連続的に值が変化する。また、単一の反射音 に対して適用できる指標であるため、ここではTs を用いて LEV の 定量化を試みた。まず、Ts に対する個々の反射音の奇与を $\mathrm{Ts}_{\mathrm{i}}$ とし て 6-1 式のように定義する。

$$
T s_{i}=\int_{0}^{\infty} t \cdot p_{i}^{2}(t) d t / \int_{0}^{\infty} p^{2}(t) d t
$$

ここで、 $p(t)$ : 無指向性インパルス応答、 $p_{i}(t):$ 方向 $i$ より到来す る反射音。

次に、知見 $\mathrm{a} 、 \mathrm{~b}$ から反射音の到来方向による LEV への寄与を考 慮し $\mathrm{Ts}_{\mathrm{i}}$ を6-2 式のように補正する。

$$
a_{i}=T s_{i} \cdot\left(1+\cos \theta_{\mathrm{Li}}\right) / 2
$$

ここで、 $a_{i}$ : 方向 $i$ より到来する反射音のレベル、時間と方向のフ アク夕、 $\theta_{\mathrm{Li}}$ : 両耳軸からの角度。また 6-2 式の $\left(1+\cos \theta_{\mathrm{L}}\right) / 2$ は 耳軸方向で最大となり、前後方向でゼロとならない変化となる。

次に、知見 $\mathrm{c} 、 \mathrm{~d} 、 \mathrm{e}$ から反射音の空間分布の定量化を検討する。 ここでは、知見 $\mathrm{c}$ の反射音の相互作用を定量化すれば、その 2 次的 な帰結として知見 d、e が説明できると考えた。まず、2つの反射 音が作用しあうことをそれぞれの $a_{i}$ を掛け合わせることで定量化 する。その際、2つの反射音の到来方向が角度的に互いに離れてい る程 LEV への寄与は大きいとした。さらに、ある反射音の LEV 八 の寄与は他の全ての反射音の影響を受けるため、他の反射音との相 互作用を全て積分することにした。これらを6-3 式のように表わす。

$$
b_{i}=a_{i} \cdot \sum_{j=0}^{n} a_{j} \cdot \sin \left(\theta_{\mathrm{ij}} / 2\right)
$$

ここで $b_{i}$ は反射音 $p_{i}(t)$ の LEV への寄与、 $\theta_{i j}$ は到来方向 $i$ と $j$ 間の 角度。

最後に、6-4 式のように全反射音の $b_{i}$ を積分して LEV への総合的 な寄与 SBTs（Spatially Balanced Ts）とする。

$$
S B T s=\sqrt{\sum_{i=0}^{n} b_{i}}=\sqrt{\sum_{i=0}^{n} \sum_{j=0}^{n} a_{i} \cdot a_{j} \cdot \sin \left(\theta_{\mathrm{ij}} / 2\right)}
$$

このように全反射音の相互作用を総当たりで定量化することの 2 次的な帰結として、知見 $\mathrm{d}$ と $\mathrm{e}$ を説明できる。インパルス応答が同 一の場合、反射音到来方向が広範用で個々の反射音の $\mathrm{Ts}_{\mathrm{i}}$ が空間的 にバランス良く分布しているときに SBTsは大きくなる。
前述のように、反射音の時間構造と空間情報は独立ではないた め、SBTs では両者を別々に扱うのではなく、反射音の時間、レ心゙ ル、到来方向さらには反射音間の相互作用などを不可分なものとし て統合的に扱っている。SBTs は、反射音エネルギの空間的なバラ ンスを考慮して時間重心Ts を払張したものと考えることもできる。

実音場の SBTs を求めるには、 $\mathrm{Ts}_{\mathrm{i}}$ を測定する必要がある。筆者 らが用いている正四面体頂点法[12]などの仮想音源測定手法を用い れば初期応答における個々の反射音の $\mathrm{Ts}_{\mathrm{i}}$ を測定することができる。 また指向性マイクロホンを用いて後部残響部までの方向別インパル ス応答を測定することで SBTs を求めることもできる。この場合、 マイクロホンの指向性が理想的なら $\mathrm{Ts}=\Sigma \mathrm{Ts}_{\mathrm{i}}$ となる。しかし、通 常の指向性マイクロホンでは測定方向間でクロストークが生じるた め $\mathrm{Ts}<\Sigma \mathrm{Ts}_{\mathrm{i}}$ となる。したがって、通常は $\mathrm{Ts} / \Sigma \mathrm{Ts}_{\mathrm{i}}$ を各方向の $\mathrm{Ts}_{\mathrm{i}}$ に乗じてクロストークの影響を補正することによって近似的に $\mathrm{Ts}_{\mathrm{i}}$ を求めることが可能である。

\section{6-3. 各実験の心理尺度值と SBTs の対応}

実験 1 から 6 で用いた各音場における SBTs む理実験結果と併 せてそれぞれ図24～図 29 に示す。これらをみると、SBTs の変 化が LEV の心理尺度值の変化と良く対応しているのがわかる。特 に、既存の物理指標では定量化できなかった実験 $2 、 3 、 4$ におけ る反射音の相互作用の影響が SBTs の值の変化に現われている。ま た、表 2 に示した各実験における SBTs と LEV の心理尺度值の相 関係数をみると、両者の間に高い相関が得られていることがわかる。

以上の結果から、反射音エネルギと時間のパラメータを含んだ Ts を用い、反射音の相互作用を考慮して空間分布を定量化するこ とでLEVを評価できる可能性が示された。
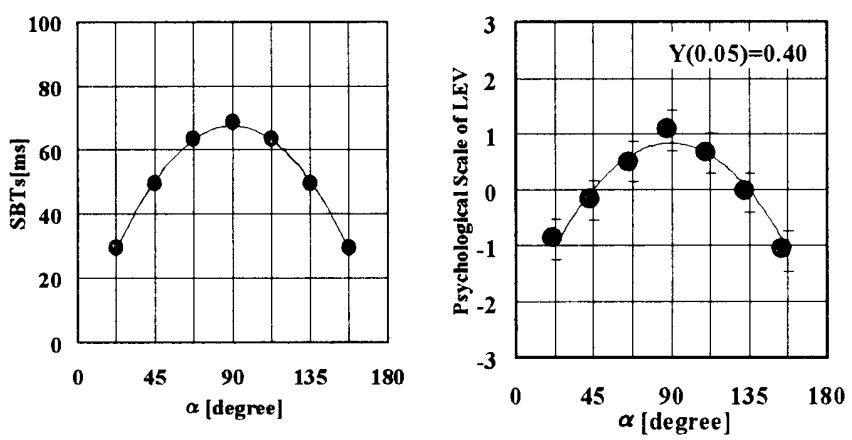

図24実験 11における SBTs と心理尺度值
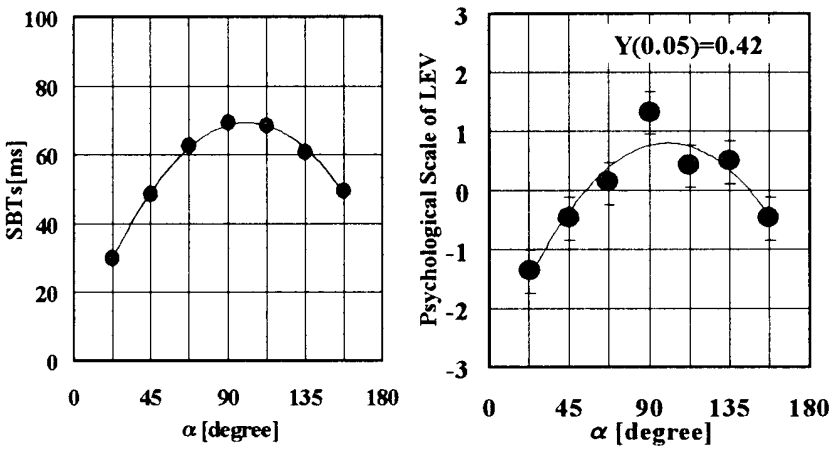

図25 実験2における SBTs と心理尺度值 

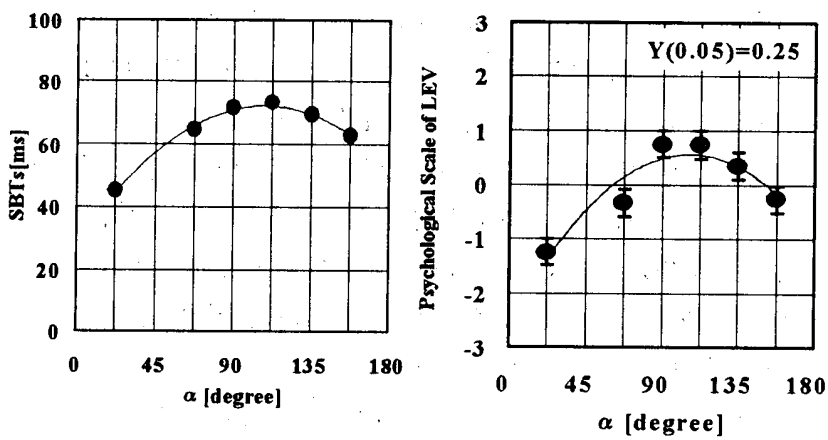

図26実験3にたおける SBTs と心理尺度值


図27実験4における SBTs と心理尺度值
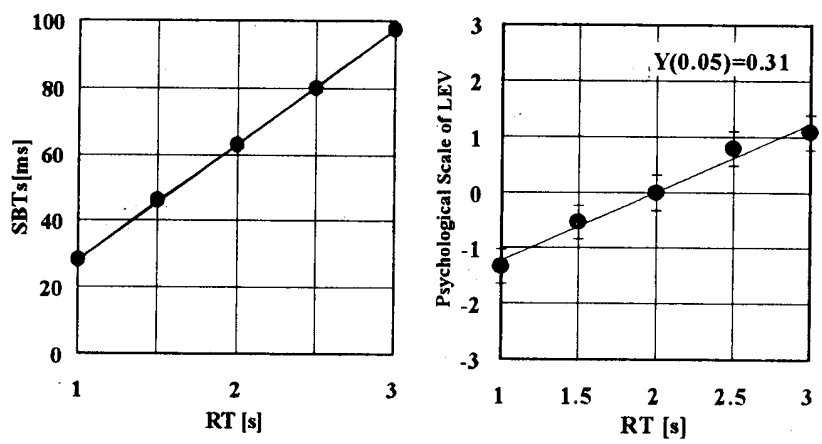

图28 実験5における SBTs と心理尺度值
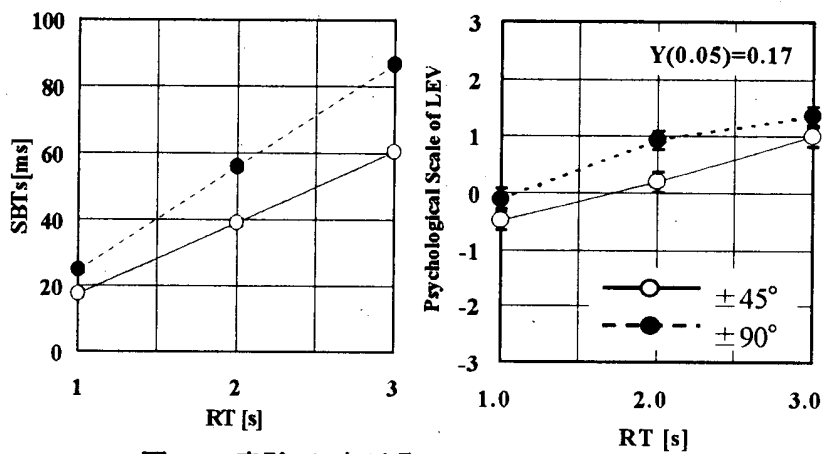

図29実験6ににおける SBTs と心理尺度佰

\section{表 2 SBTs と LEV 心理尺度值との相関係数}

\begin{tabular}{cc}
\hline Experiment No. & Correlation Coef. \\
\hline \hline 1 & $0.988^{* *}$ \\
2 & $0.942^{*}$ \\
3 & $0.959^{*}$ \\
4 & $0.967^{*}$ \\
5 & $0.991^{* *}$ \\
6 & $0.974^{* *}$ \\
\hline & ${ }^{*} \mathrm{p}<0.01^{* *} \mathrm{p}<0.001$
\end{tabular}

\section{7. まとめ}

反射音の到来方向、空間分布、残響時間、受聴レベルが音に包ま れた感じ（LEV)に及ぼす影響を7つの心理実験を行って調べた。 その結果以下の知見が得られた。

1 ）側方から到来する反射音ほどLEV への貢献が大きい。

2）正面から到来寸る反射音のLEV への影響はゼロではない。

3 ）反射音の LEV への寄与は他の反射音の到来方向に依存寸る。

4) 反射音到来方向の空間分布が広範囲の場合に LEV. が大きくな る。

5）反射音到来方向の空間的バランスが良い場合に LEV が大きく なる。

6）残響時間が長くなるとLEVは大きくなる。

7）受聴レベルが大きくなると LEV も大きくなる。

これらの知見と以前筆者らが行った基整的な心理実験[8]、お よび Bradley が行った一連の実験の結果[3,4]から導き出される知見 を説明できることが LEV の物理指標の必要条件と考之、方向別の 時間重心 $T s$ を用いて反射音の空間分布を定量化する指標として SBTs を提案した。SBTs は今回行なった心理実駼結果と良い相関を 示した。今後は、鉛直方向の反射音や受聴レベルさらには反射音の 周波数特性の影響などについて検討していくつもりである。

\section{参考文献}

[1] Barron,M., Marshall,A.H., "Spatial impression due to early lateral reflections in concert halls; the derivation of a physical measure,"J.Sound and Vib. 77(2),211-232(1981)

[2] 森本政之,藤森久嘉,前川純一,"見かけの音源の幅と音に包まれた 感じの差異,"日本音響学会誌 46,449-457(1990)

[3] Bradley,J.S., Soulodre,G'A., "The influence of late arriving energy on spatial impression, "J.Acoust.Soc.Am. 97(4), 2263-2271(1995)

[4] Bradley,J.S., Soulodre,GA., "Objective measures of listener envelopment, "J.Acoust.Soc.Am. 98(5), 2590-2597(1995)

[5] L.Beranek,Concert and opera halls(Acoustical Society of America, New York, 1996)

[6] M.Morimoto and K.lida,"A new physical measure for psychological evaluation of a sound field : FrontBack energy ratio as a measure for envelopment, "J.Acoust.Soc. Am. 93,2282 (1993)

[7] H.Furuya, K.Fujimoto, Y.Takeshima, and H.Nakamura, "Effect of early reflections from upside on auditory envelopment, "J.Acoust.Soc.Jpn.(E)16, 97-104 (1995)

[8] 羽入敏樹,木村翔,橋本修,"音による取り囲まれ方が空間印象に及 ぽ寸影響,"日本音響学会講演論文集,823-824 (1996.9)

[9] 新版 官能検查ハンドブック，日科技連官能検查委員会編，日科 技連出版社(1973)

[10] M.Barron, "The subjective effects of first reflections in concert hallsThe need for lateral reflections, "J.Sound Vib.15,475-494(1971)

[11] Thiele,R., "Richtungsverteilung und Zeitfolge der Schallruckwurfe in Raumen, "ACUSTICA 13,291-302 (1952)

[12] 関口克明, 木村翔，羽入敏樹，松本英一郎、“4 チャンネルマイク ロホンシステムを用いた正四面体頂点法による室内音場の解析、” 日本建築学会計画系論文報告集、No. 414 (1990. 8) p. 1-11

(1998年 9 月 4 日原稿受理, 1998年12月 8 日採用決定) 